Sains Malaysiana 46(9)(2017): 1549-1555

http://dx.doi.org/10.17576/jsm-2017-4609-25

\title{
Sintesis dan Sifat Termal Natrium Kanji Sulfat Dioscorea pentaphylla
}

(Synthesis and Thermal Properties of Dioscorea pentaphylla Sodium Starch Sulfate)

\author{
M.S. ELMI SHARLINA, AZWAN MAT LAZIM \& W.A. YAACOB*
}

\section{ABSTRAK}

Kanji Dioscorea pentaphylla telah diubah suai dengan pensulfatan dan peneutralan bagi menghasilkan natrium kanji sulfat. Tindak balas pensulfatan dilakukan dengan asid sulfurik dalam etanol dan air pada suhu $0^{\circ} \mathrm{C}$. Darjah penukargantian dikira berdasarkan peratus karbon dan sulfur yang ditentukan menggunakan penganalisis unsur CHNS. Natrium kanji sulfat yang mempunyai darjah penukargantian dan peratus nisbah berat hasil yang tinggi dipilih dan dicirikan dengan spektrum transformasi Fourier inframerah (FT-IR) dan profil pembelauan sinar-X (XRD). Kehadiran dua puncak getaran regangan $\mathrm{C}-\mathrm{O}-\mathrm{S}$ dan $\mathrm{S}=\mathrm{O}$ dalam spektrum FT-IR dan puncak berbeza yang terhasil dalam corak difraktogram XRD membuktikan tindak balas berlaku pada struktur kanji. Sifat termal juga ditentukan dengan kalorimeter pengimbas pembezaan (DSC) dan analisis termogravimetri (TGA). Natrium kanji sulfat yang dihasilkan mempunyai kestabilan termal yang baik kerana mempunyai suhu penguraian pada $265^{\circ} \mathrm{C}$. Natrium kanji sulfat ini sesuai dijadikan bahan tambahan dalam penghasilan hidrogel, organogel dan filem dengan sifat anionik kerana degradasi tidak terjadi di bawah suhu ini.

Kata kunci: Dioscorea pentaphylla; natrium kanji sulfat; pensulfatan

\section{ABSTRACT}

Dioscorea pentaphylla starch was modified by sulphation and neutralization to produce sodium starch sulfate. The sulphation reaction was carried out with sulphuric acid in ethanol and water at $0^{\circ} \mathrm{C}$. The degree of substitution was calculated based on the percentages of carbon and sulphur determined using CHNS elemental analyzer. Sodium starch sulfate which has high degree of substitution and percentage of yield ratio by weight was chosen and characterized by Fourier transform infrared (FT-IR) spectrum and X-ray diffraction (XRD) profile. The presence of two peaks belonging to stretching vibrations of $C-O-S$ and $S=O$ in the FT-IR spectrum and the different of peaks produced in the XRD diffraction pattern proved that the reaction occurred in the starch structure. Thermal properties were also determined using differential scanning calorimetry (DSC) and termogravimetry analysis (TGA). Sodium starch sulfate produced has a good thermal stability because of the decomposition temperature of $265^{\circ} \mathrm{C}$. Sodium starch sulfate is suitable as an additive in the production of heat resistance hydrogel, organogel and film with anionic properties because degradation does not occur below this temperature.

Keywords: Dioscorea pentaphylla; sodium starch sulfate; sulphation

\section{PENGENALAN}

Polisakarida sering diubah suai secara kimia bagi menghasilkan terbitannya, seperti pemetilan (Singh \& Tiwari 2008), pengasetilan (Chi et al.2008), pensuksinilan (Arueya \& Oyewale 2015), pengkarboksimetilan (Wang et al.2009), pengesteran (Dzulkefly et al.2007), pemfosforilan (Chowdary et al. 2011) dan pensulfatan (Yao 2000). Polisakarida sulfat lebih menarik perhatian penyelidik kerana mempunyai aktiviti biologi yang pelbagai seperti bahan antioksida (Zou et al. 2008), anti-virus (Christensen et al. 2001), anti-HIV (Katsuraya et al. 1995) dan antihemoglutinasi (Liu et al. 2003). Ciri keterlarutan dalam air (Gericke et al.2009), biodegradasi dan bioserasi (Xie et al. 2009) menyebabkan polisakarida sulfat berpotensi besar untuk digunakan dalam pembasmian kuman (Agarwal et al. 2010), sistem penyampaian ubat (Zhu et al. 2010), ejen anti-penggumpalan (Wang et al. 2007) dan pemekat perubatan (Yang et al. 1988), farmaseutik (Gohdes \& Mischinick 1998) dan aplikasi bioteknologi (Zhang et al. 2011a). Berbanding dengan banyak polisakarida lain, kanji mempunyai sumber asli yang lebih banyak, harga yang lebih rendah dan ciri mesra alam yang lebih baik (Cui et al. 2009).

Kanji sulfat adalah terbitan kanji yang bersifat anionik kerana kumpulan hidroksil pada kedudukan 2, 3 dan 6 dalam unit anhidroglukosa (AGU) kanji digantikan sebahagian atau sepenuhnya oleh kumpulan sulfat (Chen et al. 2013). Darjah penukargantian bagi kanji sulfat yang tinggi menyumbang kepada sifat dan aktiviti biologi yang lebih baik dalam pelbagai aplikasi (Cui et al. 2011). Penyediaan terdahulu kanji/selulosa sulfat dilakukan dengan reagen dan pelarut yang berlainan seperti asid klorosulfonik-natrium klorida (Sparrow et al. 1958), sulfur trioksida-dimetil sulfoksida (Whistler 1970), asid 
klorosulfonik-dimetil formamida (Zhang et al. 2011a) dan asid klorosulfonik-piridina (Zhang et al. 2011b). Beberapa kelemahan seperti kos yang tinggi, pencemaran alam sekitar dan toksik atau berbahaya telah menghadkan penghasilan kanji sulfat yang lebih meluas menggunakan kaedah yang dibincangkan awal tadi (Chen et al. 2013; Cui et al. 2011). Kaedah yang lebih baik telah dibangunkan oleh Chen et al. (2013), Cui et al. (2011) dan Yao (2000) dengan masing-masing menggunakan asid sulfurik-etanolnatrium sulfat kontang, asid sulfurik-etanol-air dan asid sulfurik-n-propanol kitar semula.

Dioscorea pentaphylla Linn. dikenali sebagai ubi pasir di Malaysia (Burkill 1966) dan ubi kasu di Kelantan dan Terengganu. Ia adalah tumbuhan yang tumbuh sendiri tanpa ditanam, boleh ditanam dan boleh dimakan (Burkill 1966). Tumbuhan ini mudah ditanam dan bebas daripada penyakit (Usher 1974). Ketiadaan maklumat mengenai tindak balas kimia bagi kanji D. pentaphylla khususnya penghasilan natrium kanji sulfat telah mendorong kajian ini dilakukan. Dalam kajian ini, kanji hidrogensulfat yang mempunyai darjah penukargantian yang tinggi disediakan daripada tindak balas kanji $D$. pentaphylla dengan asid sulfurik seperti yang pernah dilakukan oleh Cui et al. (2011) terhadap kanji ubi kentang (Solanum tuberosum). Seterusnya kanji hidrogensulfat ini ditukarkan kepada natrium kanji sulfat menggunakan natrium hidroksida mengikut kaedah Chen et al. (2013) terhadap selulosa hidrogensulfat daripada kapas. Kanji anionik tersebut kemudian dicirikan dengan spektroskopi transformasi Fourier inframerah (FTIR) dan pembelauan sinar-X (XRD) bagi membuktikan berlakunya tindak balas pada struktur kanji dan menentukan sifat termalnya menggunakan kalorimetri pengimbas pembezaan (DSC) dan analisis termogravimetri (TGA). Dalam kajian ini, kanji hidrogensulfat disintesis daripada kanji D. pentaphylla menggunakan asid sulfurik-etanol-air seperti kaedah yang dilaporkan oleh Cui et al. (2011) kerana ia mudah dan mempunyai hasil yang senang ditulenkan dengan pelarut etanol dan aseton. Kaedah ini adalah lebih mesra alam berbanding penggunaan asid klorosulfonik dan sulfur trioksida sebagai reagen serta pelarut organik yang lain seperti piridina, dimetil formamida dan cecair ionik. Walaupun begitu, kaedah yang dikemukakan oleh Cui et al. (2011) hanya menghasilkan kanji hidrogensulfat. Kanji hidrogensulfat hanya boleh disimpan dalam keadaan beku atau sejuk tetapi tidak boleh disimpan pada suhu bilik kerana kanji hidrogensulfat sensitif kepada haba. Oleh itu, natrium kanji sulfat dihasilkan melalui tindak balas peneutralan kanji hidrogensulfat dengan larutan natrium hidroksida. Sifat termal natrium kanji sulfat dikaji bagi membuktikan bahawa natrium kanji sulfat juga mempunyai kestabilan termal yang tinggi. Sifat termal natrium selulosa sulfat yang dihasilkan melalui tindak balas kimia selulosa daripada kapas dengan natrium sulfat kontang-asid sulfurik-etanol pernah dilaporkan oleh Chen et al. (2013). Penghasilan natrium kanji sulfat menggunakan kanji daripada semua spesies ubi Dioscorea masih belum dilaporkan sebelum ini termasuklah kanji ubi $D$. pentaphylla. Ini kerana kajian yang melibatkan pengubahsuaian kanji ubi Dioscorea masih baru bermula sekitar tahun 1997 dan masih terdapat lagi ruang untuk meluaskan kajian terhadap kanji daripada sumber ini.

\section{BAHAN DAN KAEDAH}

\section{BAHAN}

Kanji diekstrak daripada sampel ubi segar (Dioscorea pentaphylla Linn.) dengan kaedah Airul et al. (2014). Bahan kimia yang digunakan dalam kajian ini adalah etanol (R \& M Chemical, 95\%), aseton (Emsure, gred sintesis), asid sulfurik pekat (Sigma-Aldrich, 95-98\%) dan natrium hidroksida (R \& M Chemical, gred sintesis).

\section{PENYEDIAAN NATRIUM KANJI SULFAT}

Natrium kanji sulfat disediakan daripada kanji Dioscorea pentaphylla mengikut kaedah Chen et al. (2013) dan Cui et al. (2011) dengan beberapa pengubahsuaian. Mulamula setiap asid sulfurik $(100 \mathrm{~mL})$, etanol $(160 \mathrm{~mL})$ dan air suling $(40 \mathrm{~mL})$ disejukkan pada suhu $4^{\circ} \mathrm{C}$. Kemudian etanol dan air suling ditambah kepada kelalang dasar bulat berleher-tiga yang dilengkapi termometer dan kondenser. Kelalang itu direndam dalam kukusan ais dan natrium klorida. Kemudian asid sulfurik pekat dimasukkan sedikit demi sedikit ke dalam kelalang tadi dan larutan dikacau dengan pengacau magnet pada $400 \mathrm{rpm}$. Setelah larutan tersebut mencapai suhu $0^{\circ} \mathrm{C}$, kanji $(10 \mathrm{~g})$ dimasukkan dan campuran tindak balas dikacau selama 3 jam. Kanji hidrogensulfat yang terhasil dimendakkan dengan memasukkan aseton sejuk $4^{\circ} \mathrm{C}(100 \mathrm{~mL}) \mathrm{ke}$ dalam larutan tindak balas dan dituras vakum. Hasil turasan kanji hidrogensulfat di campur dengan air suling (1:2) dan $\mathrm{pH}$ diselaraskan kepada 9.0 menggunakan natrium hidroksida $3 \mathrm{M}$. Kemudian etanol dicampur bagi memendakkan natrium kanji sulfat, mendakan tersebut dituras vakum dan pes yang terhasil di kering sejuk-beku bagi menghasilkan serbuk natrium kanji sulfat. Peratus nisbah berat hasil dikira berdasarkan berat natrium kanji sulfat dan berat kanji (10 g). Langkah ini diulang dengan mengubah isi padu asid sulfurik daripada 100 mL kepada 130, 160, 190 dan 220 mL bagi mendapatkan peratus nisbah berat hasil dan darjah penukargantian yang optimum. Nisbah $\mathrm{m}_{\text {kanji: }}: \mathrm{V}_{\text {asid sulfurik }}, \mathrm{V}_{\text {asid sulfurik }}: \mathrm{V}_{\text {pe }}$ $, \mathrm{V}: \mathrm{V}_{\text {kanji }}$ masing-masing adalah $1: 10,1: 2$ dan $1: 4(\mathrm{~m}=$ berat, $\mathrm{V}=\mathrm{isi}$ padu).

\section{PENENTUAN DARJAH PENUKARGANTIAN}

Darjah penukargantian dikira menggunakan peratus kandungan karbon $(\mathrm{C} \%)$ dan sulfur $(\mathrm{S} \%)$ dalam natrium kanji sulfat yang diperoleh daripada penganalisis unsur CHNS (Thermo-Finnigan, EA 1112 series CHNS Analyzer, Itali) (Chen et al. 2013) seperti (1).

$$
\text { Darjah Penukargantian }=\frac{\mathrm{S} \% / 32}{\mathrm{C} \% / 72} .
$$




\section{SPEKTROSKOPI TRANSFORMASI FOURIER INFRAMERAH}

Kanji dan natrium kanji sulfat Dioscorea pentaphylla dicirikan dengan spektrometer transformasi Fourier inframerah (FT-IR, Perkin Elmer Spectrum BX FT-IR System, USA) dalam julat panjang gelombang $4000-400 \mathrm{~cm}^{-1}$ dengan bacaan pada setiap $4 \mathrm{~cm}^{-1}$. Sampel dicampurkan dengan $\mathrm{KBr}(1: 1)$, kemudian ditekan bagi menghasilkan pelet nipis dan diletakkan pada spektrofotometer FT-IR untuk direkodkan (Cui et al. 2011).

\section{PEMBELAUAN SINAR-X (XRD)}

Pembelauan Sinar-X (XRD, Bruker D8 Advance, German) diguna bagi membuktikan tindak balas berlaku pada struktur kanji dan bagi menentukan darjah penghabluran kanji dan natrium kanji sulfat. Sampel dimasukkan ke dalam pemegang sampel dan corak difraktogram direkodkan pada mod refleksi 5-80 $(2 \theta)$ pada suhu bilik yang beroperasi pada $40 \mathrm{kV}$ dan $40 \mathrm{~mA}$ dengan sinaran $\mathrm{K} \alpha \mathrm{Cu}, \mathrm{k}=0.5406 \mathrm{~nm}$ (Regina et al. 2016).

\section{KALORIMETRI PENGIMBAS PEMBEZAAN (DSC)}

Suhu pengelatinan kanji ditentukan dengan Kalorimetri Pengimbas Pembezaan (DSC 822 Mettler Toledo, Switzerland). Kanji (10 mg) ditimbang dalam periuk aluminium kecil dan air ternyahion dimasukkan dalam nisbah 1:3 bagi menghasilkan ampaian kanji. Periuk dimeterai dan dibiarkan pada suhu bilik selama 1 jam sebelum dipanaskan pada julat suhu 20 hingga $120^{\circ} \mathrm{C}$ dengan kadar pemanasan $10^{\circ} \mathrm{C} / \mathrm{min}$. DSC ini dikalibrasi dengan indium dan periuk aluminium kecil sebagai pengosong. Suhu pemula $\left(\mathrm{T}_{\mathrm{o}}\right)$, suhu puncak $\left(\mathrm{T}_{\mathrm{p}}\right)$, suhu penamat $\left(\mathrm{T}_{\mathrm{c}}\right.$ ) dan entalpi pengelatinan ditentukan (Cui et al. 2011).

\section{ANALISIS TERMOGRAVIMETRI (TGA)}

Analisis kestabilan termal ditentukan dengan analisis termogravimetri (TGA 50 Shimadzu, Jepun). Kira-kira 10 mg kanji dipanaskan daripada suhu bilik sehingga $550^{\circ} \mathrm{C}$ pada kadar pemanasan $15^{\circ} \mathrm{C} / \mathrm{min}$ dalam aliran gas nitrogen (Chen et al. 2013).

\section{KEPUTUSAN DAN PERBINCANGAN}

\section{HASIL (\%) DAN DARJAH PENUKARGANTIAN}

Darjah penukargantian (DP) adalah parameter penting bagi kanji ubah suai kerana ia mempengaruhi sifat kanji yang dihasilkan. Ia didefinisikan sebagai bilangan purata kumpulan hidroksil yang ditukar ganti per unit glukosa dalam struktur kanji (Cui et al. 2011). Nilai maksimum bagi DP adalah 3. Ini kerana setiap unit glukosa dalam struktur kanji mempunyai tiga kumpulan hidroksil yang mempunyai kebarangkalian ditukar ganti oleh kumpulan sulfat. Semakin tinggi nilai DP bermaksud semakin banyak kumpulan hidroksil ditukar ganti kepada kumpulan sulfat (Chen et al. 2013).
Asid sulfurik digunakan sebagai agen pensulfatan dalam medium tindak balas kerana reagen ini murah, tidak membentuk hasil sampingan organik, hasilnya mudah ditulenkan dan kurang tercemar (Cui et al. 2011). Amaun asid sulfurik yang digunakan dalam kajian ini adalah 100, 130, 160, 190 dan $220 \mathrm{~mL}$. Amaun asid sulfurik rendah akan menghasilkan natrium kanji sulfat yang mempunyai peratus nisbah berat hasil yang tinggi (Rajah 1) tetapi darjah penukargantian yang rendah (Rajah 2) manakala kandungan asid sulfurik yang tinggi pula meningkatkan darjah penukargantian tetapi menurunkan peratusan hasil. Amaun asid sulfurik yang terlalu tinggi mendorong kepada kerosakan yang lebih kepada struktur kanji akibat daripada berlakunya pengkarbonan rantai kanji (penyahhidratan) dan pemutusan rantai kanji (hidrolisis) (Cui et al. 2011). Amaun asid sulfurik dalam penghasilan natrium kanji sulfat yang optimum ialah $130 \mathrm{~mL}$ yang menghasilkan $89 \%$ nisbah berat hasil dan darjah penukargantian 1.90 (Rajah 2). Nilai ini hampir sama seperti apa yang diperoleh dalam kajian Cui et al. (2011) (darjah penukargantian, DP = 1.85) yang menggunakan kanji ubi kentang pada keadaan tindak balas yang optimum pada nisbah $\mathrm{m}_{\mathrm{knj}} / \mathrm{V}_{\mathrm{H} 2 \mathrm{SO} 4}=0.075 \mathrm{~g} /$ $\mathrm{mL}, \mathrm{V}_{\mathrm{EtOH}} / \mathrm{V}_{\mathrm{H} 2 \mathrm{SO} 4}=1.4, \mathrm{~V}_{\mathrm{H} 2 \mathrm{O}} / \mathrm{V}_{\mathrm{EtOH}}=0.25$, suhu tindak balas $0^{\circ} \mathrm{C}$ dan masa tindak balas 4.5 jam. Nilai ini didapati lebih tinggi berbanding kajian yang dilakukan oleh Chen et al. (2013) yang menggunakan asid sulfurik, etanol dan natrium sulfat sebagai bahan tindak balas dengan DP natrium selulosa sulfat yang terhasil ialah antara 0.28 dan 0.77 . Penggunaan pelarut organik nampaknya akan menghasilkan natrium kanji/selulosa sulfat yang mempunyai DP optimum yang lebih tinggi seperti kajian yang dilaporkan oleh Cui et al. (2009) (kanji ubi kentang-asid klorosulfonik-piridina, DP $=2.21$ ), Zhang et al. (2011b) (selulosa-asid klorosulfonik-dimetil formamida, DP = 2.59), Zhang et al. (2011a) (selulosaasid klorosulfonik-N,N-asetamida/litium klorida, DP = 2.59).

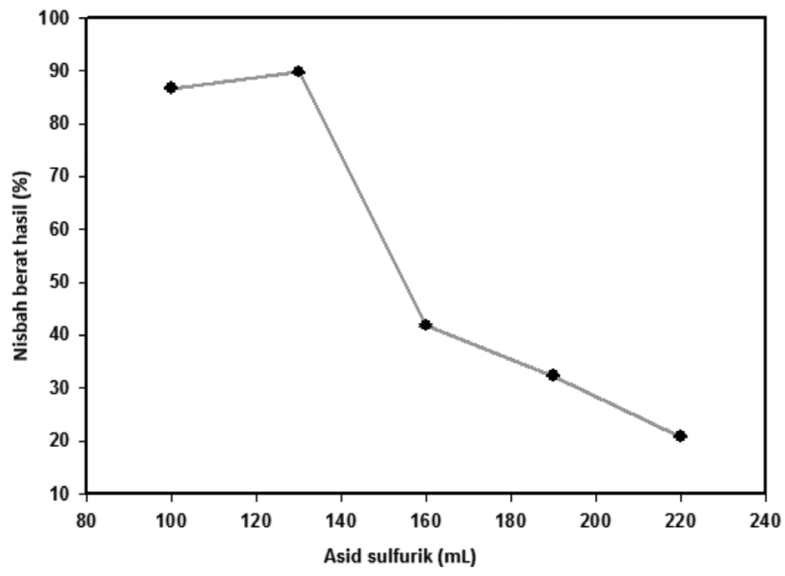

RAJAH 1. Natrium kanji sulfat (\%) yang terhasil menggunakan isi padu asid sulfurik yang berlainan 


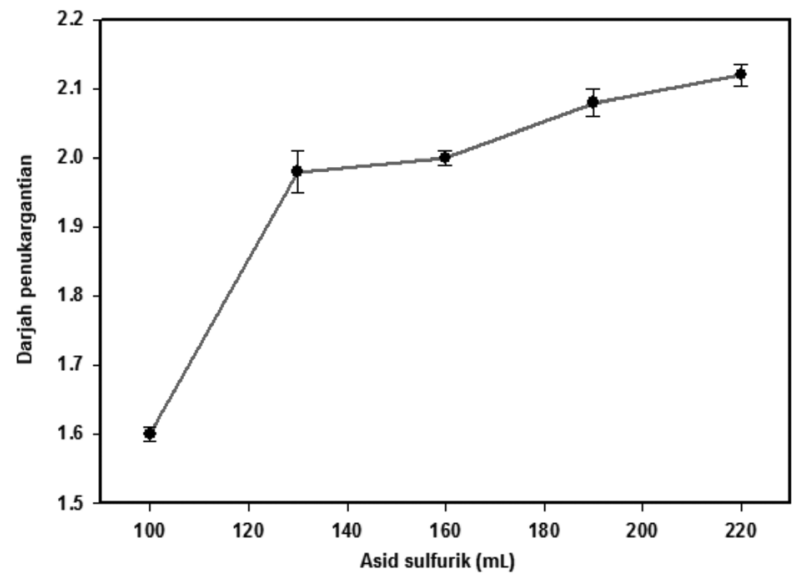

RAJAH 2. Darjah penukargantian natrium kanji sulfat pada isi padu asid sulfurik yang berlainan

Etanol dipilih sebagai pelarut dalam kajian ini kerana ia dapat mengurangkan pengkarbonan dan degradasi seperti yang dilaporkan oleh Chen et al. (2013) dan Cui et al. (2011). Oleh kerana kanji tidak melarut dalam etanol, air memainkan peranan penting sebagai penghantar reagen pensulfatan memasuki ke dalam granul kanji dan menukarganti kumpulan hidroksil pada struktur kanji dengan kumpulan sulfat (Cui et al. 2011). Tindak balas dalam medium berasid biasanya sensitif kepada suhu yang menyebabkan berlakunya degradasi dan pengkarbonan pada rantai struktur kanji. Campuran tindak balas akan bertukar menjadi hitam apabila suhu tindak balas meningkat kepada $10^{\circ} \mathrm{C}$ dalam masa 3 jam, $20^{\circ} \mathrm{C}$ dalam masa 2 jam dan $30^{\circ} \mathrm{C}$ dalam masa 1 jam. Warna medium tindak balas yang berubah menjadi gelap bermaksud berlakunya pengkarbonan. Oleh itu, suhu yang digunakan dalam kajian ini adalah $0^{\circ} \mathrm{C}$ bagi mengelakkan daripada berlakunya pengkarbonan semasa tindak balas pensulfatan kanji disebabkan oleh penguraian dalam struktur kanji. Keputusan ini disokong oleh keputusan yang dilaporkan oleh Cui et al. (2011). Oleh itu, adalah amat penting untuk memastikan suhu tindak balas tidak melebihi $5^{\circ} \mathrm{C}$ semasa tindak balas pensulfatan dilakukan. Tindak balas ini juga boleh dilakukan pada suhu lebih rendah daripada $0^{\circ} \mathrm{C}$ seperti yang telah dilakukan oleh Chen et al. (2013) iaitu pada suhu $-5^{\circ} \mathrm{C}$ hingga $-2^{\circ} \mathrm{C}$. Suhu yang yang lebih rendah tidak dikaji kerana faktor peningkatan kos penghasilan pada skala besar. Penyelidik juga telah menggunakan isopropanol sebagai pelarut tetapi proses karbonisasi terlalu cepat berlaku menyebabkan larutan tindak balas menjadi hitam selepas 10 min. Walaupun keadaan tindak balas berasid boleh membawa kepada kemusnahan dan penukargantian pelbagai dalam rantai kanji, proses yang mudah dan selamat tanpa menggunakan reagen yang toksik dapat menggalakkan penyediaan kanji sulfat dalam industri (Chen et al. 2013).

Tindak balas dilakukan pada suhu yang rendah bagi mengelakkan berlakunya pengkarbonan dan degradasi pada struktur kanji dan pada masa yang sama akan menurunkan kadar pensulfatan. Oleh itu, masa yang lebih lama diperlukan supaya asid sulfurik dapat menembusi granul kanji dan tindak balas pensulfatan yang lengkap berlaku. Darjah penukargantian meningkat apabila masa tindak balas yang lebih lama digunakan. Masa yang optimum bagi menghasilkan natrium kanji sulfat daripada kanji Dioscorea pentaphylla adalah 3 jam (Rajah 3). Selepas 3 jam, DP akan tetap sama dan proses pengkarbonan diperhatikan berlaku.

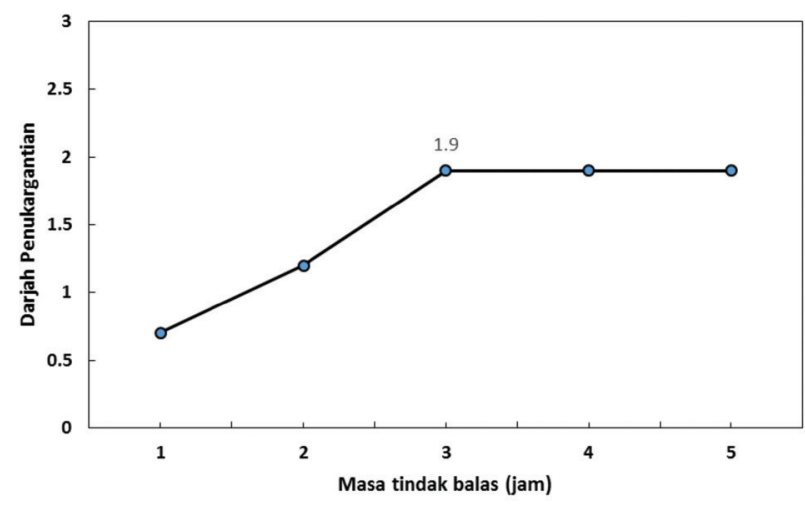

RAJAH 3. Darjah penukargantian natrium kanji sulfat pada masa tindak balas yang berlainan

\section{ANALISIS FT-IR}

Rajah 4 menunjukkan spektrum FT-IR bagi kanji asal dan natrium kanji sulfat. Seperti juga kanji asal, terbitan natrium kanji sulfat juga memberikan puncak serapan pada 3428 (regangan -OH; kuat), 1645 (getaran mengunting O-H daripada molekul air yang melekat), 1119 dan 1062 (getaran lenturan C-O-C), 1014 (lenturan O-H daripada struktur kanji) dan $615 \mathrm{~cm}^{-1}$ (getaran lenturan $\mathrm{C}-\mathrm{OH}$ ). Dua puncak serapan yang membuktikan terhasilnya natrium kanji sulfat adalah puncak pada 1233 (regangan $\mathrm{S}=\mathrm{O}$ ) dan $821 \mathrm{~cm}^{-1}$ (regangan C-O-S) yang tidak hadir pada kanji asal manakala puncak getaran lenturan $1393 \mathrm{~cm}^{-1}$ menunjukkan berlakunya pengurangan kumpulan $-\mathrm{CH}_{2} \mathrm{OH}$ dari kanji asal ke natrium kanji sulfat. Nilai puncak serapan ini hampir sama dengan nilai yang dilaporkan oleh Cui et al. 2011. Ini membuktikan tindak balas penukargantian berlaku pada struktur kanji.

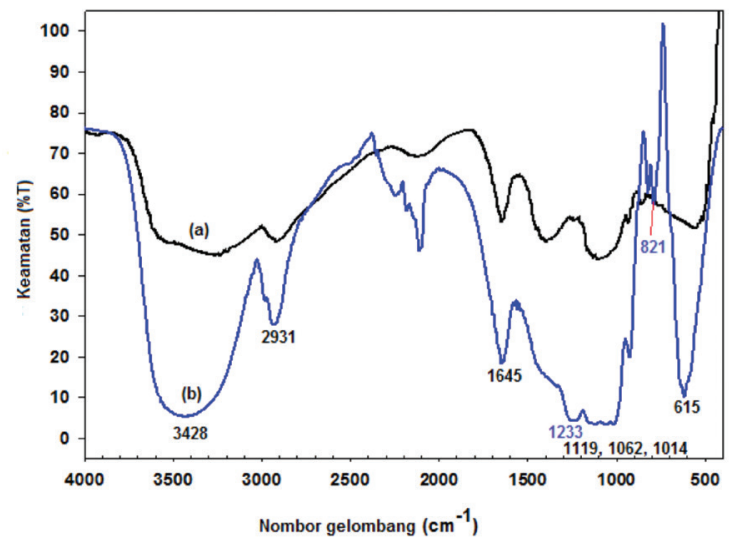

RAJAH 4. Spektrum FTIR bagi (a) kanji asal dan (b) natrium kanji sulfat Dioscorea pentaphylla 


\section{ANALISIS XRD}

Rajah 5 menunjukkan difraktogram bagi (a) kanji asal dan (b) natrium kanji sulfat Dioscorea pentaphylla yang direkodkan dalam kajian ini. Profil pembelauan sinar-X digunakan bagi mengkaji darjah penghabluran kanji dan membuktikan tindak balas berlaku pada struktur kanji yang menghasilkan natrium kanji sulfat. Anjakan puncak pada difraktogram (b) yang berbeza dengan puncak pada difraktogram (a) membuktikan tindak balas berlaku pada struktur kanji. Kanji asal bersifat semi-hablur yang terdiri daripada amorfus dan hablur. Pengubahsuaian kanji kepada natrium kanji sulfat menyebabkan meningkatnya darjah penghabluran kanji daripada 32\% (kanji asal) kepada $70 \%$ (natrium kanji sulfat). Keputusan ini pertama kali dilaporkan dan setakat ini hanya kanji hidrogensulfat sahaja dilaporkan tetapi pada keadaan tindak balas dan kanji daripada sumber yang berlainan. Dalam kajian Cui et al. (2011), kanji hidrogensulfat yang belum dineutralkan kepada natrium kanji sulfat mempunyai banyak struktur amorfus.

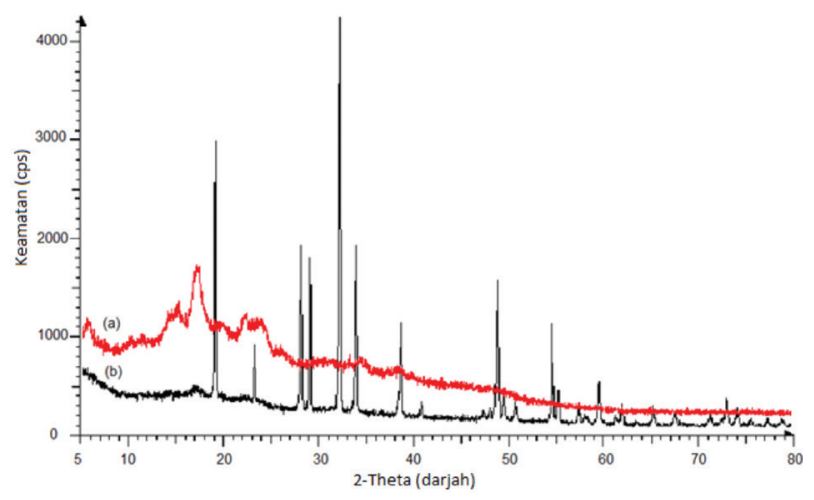

RAJAH 5. Profil XRD bagi (a) kanji asal dan (b) natrium kanji sulfat Dioscorea pentaphylla

\section{ANALISIS DSC}

Rajah 6 menunjukkan termogram DSC bagi kanji dan natrium kanji sulfat Dioscorea pentaphylla. Tindak balas kanji dengan asid sulfurik menyebabkan suhu pengelatinan kanji hidrogensulfat semakin berkurang dan akhirnya tidak dijumpai bergantung pada darjah penukargantian (Cui et al. 2011). Semasa proses pensulfatan, air memasuki granul kanji dengan memutuskan ikatan hidrogen antara molekul kanji dan ikatan hidrogen dalam molekul kanji yang menyebabkan kanji membengkak dan air memasuki rantau hablur dan menukarkan struktur hablur kepada struktur amorfus (Cui et al. 2011). Pembengkakan ini masih tidak banyak berubah semasa tindak balas peneutralan kanji hidrogensulfat dengan natrium hidroksida kepada natrium kanji sulfat. Walau bagaimanapun, semasa peneutralan molekul natrium kanji sulfat tersusun semula menyebabkan struktur amorfus telah bertukar menjadi struktur hablur seperti yang diperlihatkan dalam profil XRD. Oleh itu, tiada suhu pengelatinan dicerap bagi natrium kanji sulfat yang disediakan.

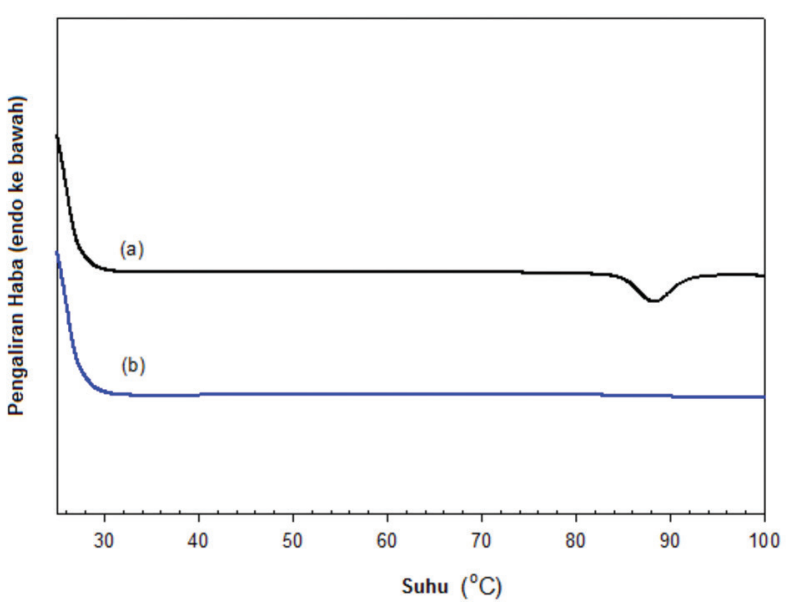

RAJAH 6. Suhu pengelatinan (a) kanji asal dan (b) natrium kanji sulfat Dioscorea pentaphylla

\section{ANALISIS TGA}

Sifat termal daripada segi peratus kehilangan berat dan suhu penguraian dapat ditentukan melalui keluk TGA dan pembezaan termogravimetri (DTG). Dalam kajian ini, proses penguraian termal berlaku dalam tiga peringkat dan kehilangan berat keseluruhan (Rajah 7) adalah 56\%. Peringkat pertama adalah proses penyahhidratan natrium kanji sulfat pada suhu sehingga $120^{\circ} \mathrm{C}$ dengan kehilangan berat $10 \%$ daripada berat asal. Peringkat kedua adalah proses pemutusan rantai amilosa dan amilopektin (Liu et al. 2010) pada julat suhu antara 230 dan $290^{\circ} \mathrm{C}$ manakala peringkat ketiga pula adalah pada suhu melebihi $400^{\circ} \mathrm{C}$ yang menghasilkan karbon yang lengai (LondonoRestrepo et al. 2014). Puncak yang tajam pada keluk DTG menunjukkan tindak balas penguraian berlaku dengan cepat pada julat suhu antara 230 dan $290^{\circ} \mathrm{C}$. Suhu penguraian natrium kanji sulfat yang terhasil adalah pada $265^{\circ} \mathrm{C}$ berbanding kanji asal $\left(309^{\circ} \mathrm{C}\right)$. Nilai ini lebih tinggi jika dibandingkan dengan natrium selulosa sulfat yang dilaporkan oleh Chen et al. (2013) (natrium selulosa sulfat, $242^{\circ} \mathrm{C}$; selulosa asal, $325^{\circ} \mathrm{C}$ ). Oleh itu, dapat dirumuskan natrium kanji sulfat ini mempunyai kestabilan termal yang baik (Elmi et al. 2017) kerana tiada penguraian berlaku di bawah suhu $265^{\circ} \mathrm{C}$. Oleh itu, natrium kanji sulfat ini dapat dijadikan bahan tambahan dalam proses penghasilan hidrogel, organogel dan filem yang lebih rintang kepada suhu kerana ia tidak mudah terurai apabila dipanaskan.

\section{KESIMPULAN}

Natrium kanji sulfat daripada kanji ubi Dioscorea pentaphylla berjaya dihasilkan melalui tindak balas pensulfatan menggunakan asid sulfurik, etanol dan air yang diikuti oleh tindak balas peneutralan dengan larutan natrium hidroksida. Kedaan tindak balas yang optimum adalah pada isi padu asid sulfurik $130 \mathrm{~mL}$ yang menghasilkan natrium kanji sulfat sebanyak $89 \%$ dengan darjah penukargantian 1.90. Spektrum FT-IR dan profil XRD membuktikan tindak balas berlaku pada struktur kanji. 

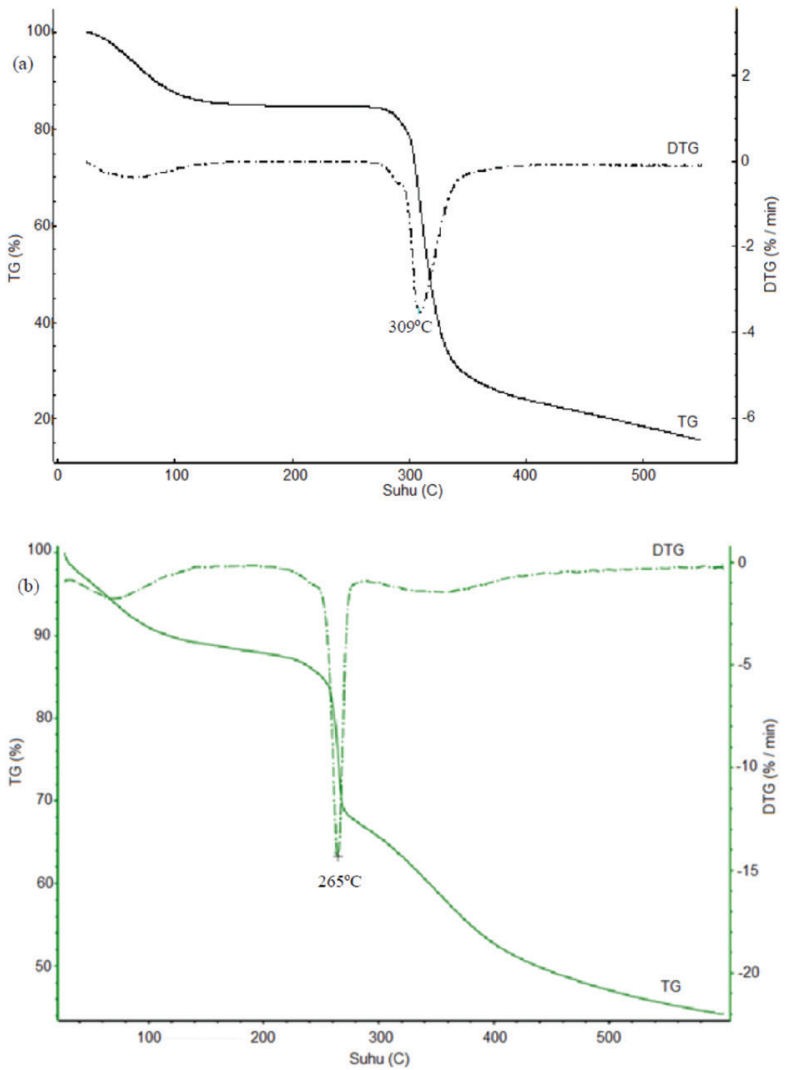

RAJAH 7. Keluk termogravimetri bagi (a) kanji asal dan (b) natrium kanji sulfat Dioscorea pentaphylla

Dua puncak serapan penting muncul dalam spektrum FT-IR pada 1233 dan $821 \mathrm{~cm}^{-1}$ dengan masing-masing mewakili getaran regangan $\mathrm{S}=\mathrm{O}$ dan $\mathrm{C}-\mathrm{O}-\mathrm{S}$. Profil XRD pula menunjukkan puncak daripada kanji asal yang berbeza daripada puncak natrium kanji sulfat. Kehadiran puncak yang lebih tajam dalam profil natrium kanji sulfat bermakna kanji asal telah bertukar daripada struktur amorfus yang lebih banyak kepada struktur hablur yang lebih banyak dalam natrium kanji sulfat. Analisis termal menunjukkan natrium kanji sulfat mempunyai kestabilan termal yang tinggi kerana suhu penguraiannya pada $265^{\circ} \mathrm{C}$. Berbanding dengan kajian terdahulu, walaupun darjah penukargantian adalah lebih kurang sama, tetapi natrium kanji sulfat yang dihasilkan ini mempunyai kelebihan daripada segi kestabilan termal dan proses penyediaannya lebih murah, senang dan mesra alam. Natrium kanji sulfat ini berguna bagi tujuan aplikasi bioteknologi, perubatan, farmaseutikal dan produk penjagaan diri.

\section{PENGHARGAAN}

Penulis ingin merakamkan ucapan terima kasih kepada KPM, KPT, UKM, CRIM dan juga geran penyelidikan DLP2014-019, DIP-2014-16, FRGS/1/2014/ST01/UKM/03/1, GUP-2014-079, GUP-2016-014, KOMUNITI-2014-010 dan PRGS/1/2014/TK04/UKM/03/1 serta biasiswa Hadiah Latihan Persekutuan (HLP) kepada Elmi Sharlina Binti Md Suhaimi.

\section{RUJUKAN}

Agarwal, H.K., Kumar, A., Doncel, G.F. \& Parang, K. 2010. Synthesis, antiviral and contraceptive activities of nucleosidesodium cellulose sulfate acetate and succinate conjugates. Bioorganic \& Medicinal Chemistry Letters 20: 6993-6997.

Airul, A., Yusof, S.M., Jamil, M.S., Abdullah, A., Yusoff, S.F.M., Arip, M.N.M. \& Lazim, A.M. 2014. Physicochemical characterization of starch extracted from Malaysian wild yam (Dioscorea hispida Dennst.). Emirates Journal of Food Agriculture 26(8): 652-658.

Arueya, G.L. \& Oyewale,T.M. 2015. Effect of varying degrees of succinylation on the functional and morphological properties of starch from acha (Digitaria exilis Kippis Stapf). Food Chemistry 177: 258-266.

Burkill, I.H. 1966. A Dictionary of the Economic Products of the Malay Peninsula. Kuala Lumpur, Malaysia, Government of Malaysia and Singapore. I (A-H).

Chen, G., Zhang, B., Zhao, J. \& Chen, H. 2013. Improved process for the production of cellulose sulfate using sulfuric acid/ ethanol solution. Carbohydrate Polymers 95: 332-337.

Chi, H., Xu, K., Wu, X., Chen, Q., Xue, D., Song, C., Zhang, W. $\&$ Wang, P. 2008. Effect of acetylation on properties of corn starch. Food Chemistry 106: 923-928.

Chowdary, K.P.R., Enturi, V. \& Rani, A.S. 2011.Preparation and evaluation of starch phosphate - A new modified starch as a disintegrant in tablet formulations. International Journal of Chemical Sciences 9(2): 889-899.

Christensen, N.D., Reed, C.A., Culp, T.D., Hermonat, P.L., Howett, M.K. \& Anderson, R.A. 2001. Papillomavirus microbial activities of high molecular weight cellulose sulfate, dextran sulfate and polystyrene sulfonate. Antimicrobial Agents and Chemotherapy 45: 3427-3432.

Cui, D., Liu, M., Zhang, B., Gong, H. \& Bi, Y. 2011. Optimization of reaction conditions for potato starch sulphate and its chemical and structural characterization. Starch/Starke 63: 354-363.

Cui, D., Liu, M., Wu, L. \& Bi, Y. 2009. Synthesis of potato starch sulfate and optimization of the reaction condition. International Journal of Biological Macromolecules 44: 294-299.

Dzulkefly, K.K.D., Koon, S.Y., Kassim, A., Sharif, A. \& Abdullah, A.H. 2007. Chemical modification of sago starch by solventless esterification with fatty acid chlorides. The Malaysian Journal of Analytical Sciences 11(2): 395-399.

Elmi Sharlina, M.S., Yaacob, W.A., Azwan, M.L., Shazrul, F., Lim, S.J., Sapina, A., Akram, N. \& Malina, K. 2017. Physicochemical properties of starch from Dioscorea pyrifolia tubers. Food Chemistry 220: 225-232.

Gericke, M., Liebert, T. \& Heinze, T. 2009. Interaction of ionic liquids with polysaccarides, 8-synthesis of cellulose sulfates suitable for polyelectrolyte complex formation. Macromolecular Bioscience 9(4): 343-353.

Gohdes, M. \& Mischnick, P. 1998. Determination of the substitution pattern in the polymer chain of cellulose sulfates. Carbohydrate Research 309: 109-115.

Katsuraya, K., Shibuya, T., Inazawa, K. \& Nakashima, H. 1995. Synthesis of sulfated alkyl malto-oligosaccharides with potent inhibitory effects on AIDS virus infection. Macromolecules 28: 6697-6700.

Liu, G.G., Borjihan, G., Baigude, H., Nakasima, H. \& Uryu, T. 2003. Synthesis and anti-HIV activity of sulfated astragalus polysaccharide. Polymer for Advanced Technologies 14(7): 471-476. 
Liu, X., Yu, L., Xie, F., Li, M., Chen, L. \& Li, X. 2010. Kinetics and mechanisme of thermal decomposition of corn starches with different amylose/amylopectin ratios. Starch/Starke 62: 139-146.

Londono-Restrepo, S.M., Rincon-Londono, N., ContrerasPadilla, M., Acosta-Osorio, A., Bello-Perez, L.A., LucasAguirre, J.C., Quintero, O.V., Pineda-Gomez,P., Real-Lopez, A. \& Rodriguez-Garcia, M.E. 2014. Physicochemical, morphological and rheological characterization of Xanthosoma robustum lego-like starch. International Journal of Biological Macromolecules 65: 222-228.

Regina, S.A.S., Wan Yaacob, W.A., Shazrul, F., Nurul, I.H. \& Azwan, M.L. 2016. Transformation of crystalline starch nanoparticles into highly luminescent carbon nanodots: Toxicity studies and their application. Carbohydrate Polymers 137: 488-496.

Singh, V. \& Tiwari,A. 2008. Microwave-accelerated methylation of starch. Carbohydrate Research 343: 151-154.

Sparrow, D.B., Pa., M., Powers, W.R., Grove, P. \& Pa., C. 1958. Method of Making Sodium Cellulose Sulfate. US Patent No. 2862922.

Usher, G. 1974. A Dictionary of Plants Used by Man. London: Constable and Company Ltd.

Wang, Y., Gao, W. \& Li, X. 2009. Carboxymethyl Chinese yam starch: Syntesis, characterisation and influence of reaction parameters. Carbohydrate Research 344: 1764-1769.

Wang, Z.M., Li, L., Zheng, B.S., Normakhamatov, N. \& Guo, S.Y. 2007. Preparation and anticoagulation activity of sodium cellulose sulfate. International Journal of Biological Macromolecules 41: 376-382.

Whistler, R.L. 1970. Process of Preparing Cellulose Sulfate and Starch Sulfate. US Patent No. 3507655.

Xie, Y.L., Wang, M.J. \& Yao, S.J. 2009. Preparation and characterization of biocompatible microcapsules of sodium cellulose sulfate/chitosan by means of layer-by-layer selfassembly. Langmuir 25(16): 8999-9005.
Yao, S. 2000. An improved process for the preparation of sodium cellulose sulphate. Chemical Engineering Journal 78: 199-204.

Yang, K.X., Ling, X.Q. \& Qu, T.Z. 1988. Influences of external salt on the solution viscosity of sodium-cellulose sulfate halfester. Acta Physico-Chimica Sinica 4(5): 523-526.

Zhang, K., Brendler, E., Geissler, A. \& Fischer, S. 2011a. Synthesis and spectroscopic analysis of cellulose sulfates with regulable total degrees of substitution and sulfation pattern via ${ }^{13} \mathrm{C}$ NMR and FT Raman Spectroscopy. Polymer 52: 26-32.

Zhang, K., Peschel, D., Baucker, E., Groth, T. \& Fischer, S. 2011b. Synthesis and characterisation of cellulose sulfates regarding the degrees of substitution, degree of polymerisation and morphology. Carbohydrate Polymers 83: 1659-1664.

Zhu, L.Y., Lin, D.Q. \& Yao, S.J. 2010. Biodegradation of polyelectrolyte complex films composed of chitosan and sodium cellulose sulfate as the controllable release carrier. Carbohydrate Polymers 82: 323-328.

Zou, C., Du, Y.M., Li, Y. \& Yang, J.H. 2008. Preparation of lacquer polysaccharide sulfates and their antioxidant activity in vitro. Carbohydrate Polymers 73: 322-331.

Pusat Pengajian Sains Kimia dan Teknologi Makanan

Fakulti Sains dan Teknologi

Universiti Kebangsaan Malaysia

43600 UKM Bangi, Selangor Darul Ehsan

Malaysia

*Pengarang untuk surat-menyurat; email: wanyaa@ukm.edu.my

Diserahkan: 6 September 2016

Diterima: 29 April 2017 